\title{
DE PAN AMERIKAANSE SANITAIRE ORGANISATIE (P.A.S.O.) IN VERBAND MET SURINAME EN DE NED. ANTILLEN ${ }^{1}$ )

\author{
DOOR
}

\section{N. H. SWellengrebel ${ }^{2}$ )}

Op het terrein van internationale samenwerking is de Nieuwe Wereld de Oude vooruit. Niet de hele Nieuwe Wereld, maar dat deel ervan dat geen banden heeft met het Britse Gemenebest, Nederland, Frankrijk, of Denemarken, dus de 21 Amerikaanse republieken. De Amerikaanse Volkenbond bestaat sedert 1890, eerst onder de naam van „Union of American Republics”, sedert 1948 onder die van "Organisation of American States". Deze Unie is dus ouder dan de zwakste Oude-Wereld pogingen in die richting: de Vredes Conferenties; en ook ouder dan het Haagse Hof, de Volkenbond, en de Verenigde Naties. In de jaren van haar bestaan is zij, als internationaal instrument, vrij wat effectiever gebleken dan haar Oude-Wereld zusters. Zij heeft niet altijd oorlogen tussen haar leden weten te voorkomen, maar ze heeft die steeds, in tijd en omvang, tot een vrij onbelangrijk minimum weten te beperken.

Haar talen zijn Engels, Spaans, Portugees en Frans. Spaans is bepaald de hoofdtaal, de beide grootste Republieken, U.S. en Brazilië, geven het blijkbaar gaarne de voorrang. Vele afgevaardigden spreken alléén Spaans, maar geen spreekt er deze taal niét. Frans, alleen op Haïti, is practisch van geen betekenis.

Het hoofdkwartier, het Palais des Nations van het Westelijk Halfrond, heet Pan-American Union, aan 17th street en Constitution Ave., in Washington D.C., gelegen. Daar zetelen de Trygve

1) Lezing welke op de 15 e Ledenvergadering van de ,Natuurwetenschappelijke Studiekring voor Suriname en de Nederlandse Antillen", op 22 Nov. 1951, werd gehouden.

$\left.{ }^{2}\right)$ Instituut voor Tropische Hygiëne en Geographische Pathologie (Afdeling van het Koninklijk Instituut voor de Tropen), Amsterdam.

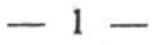

West-Indische Gids XXXIII 
N. H. SWELLENGREBEL

Lie van deze Organisatie, de Secretaris Generaal dr Alberto Lleras (Colombia) en de Assistant Secretary General, dr WiLLIAM MANGeR (U.S.A.). Daar vergadert de Council, vertegenwoordigers van alle Republieken, 2 maal per maand. Daar ook komt de Raad van Ministers bijeen in gevallen van urgentie, bijgestaan door de Advisory Defence Committee. Eens in de 5 jaar komt de Inter-American Conference bijeen; deze vergadert niet uitsluitend in Washington, maar in een van de 21 Amerikaanse hoofdsteden. De Conference is de hoogste autoriteit. Haar samenstelling is gelijk aan die van de Council. maar elke staat kan zoveel afgevaardigden zenden als hij wil. Evenals in de Council heeft elke staat maar één stem, of het nu de U.S. is, met over de 100 millioen of Panamá met 600.000 inwoners.

Op het O.Halfrond wordt U.N.O. in haar werkzaamheden bijgestaan door een aantal gespecialiseerde organisaties, die wel bij haar horen maar binnen dit verband autonoom zijn, zoals World Health Organisation, International Labour Office, Food \& Agricultural Organisation. Ook de Organisatie van Amerikaanse Staten heeft zulke "Specialized Agencies" voor bescherming van kinderen, Geographie \& Historie, Landbouw Wetenschappen, de Indianen. Over een van deze wil ik het nader hebben.

Het is de Pan American Sanitary Organisation, door de Angelsaksische minderheid tot P.A.S.O., door de Latijnse meerderheid tot O.S.P.A. afgekort, welke laatste afkorting natuurlijk veel meer gebruikt wordt, ook omdat zij zowel de organisatie, als haar hoofdkwartier, het Pan American Sanitary Bureau, aanduidt, waarvoor de Angelsaksers P.A.S.B. nodig hebben. P.A.S.O. is de oudste internationale sanitaire organisatie. $\mathrm{Zij}$ dateert van 1902, terwijl de oudste in de Oude Wereld, de Office International de Santé Publique, pas in 1907 werd gesticht. Ook hierin is de Nieuwe Wereld de Oude een flink stuk vooruit.

Alle 21 Amerikaanse Republieken zijn leden van deze Organisatie en dragen aan de kosten bij, naar rato van het aantal hunner inwoners en van hun economische draagkracht. In 1950 droeg U.S. $\$ 1.247 .147$ bij, Costa Rica $\$ 2.735$, aan een budget van $\$ 1.742$. 035. De invloed van alle staten is echter even groot. Ze hebben elk een stem in de Directing Council die eens per jaar bijeenkomt, en in de Conference (de hoogste autoriteit) die eens in de 4 jaar vergadert. Het lopende werk wordt door de Executive Committee afgedaan, die 2 of 3 keer per jaar bijeenkomt en uit 7 leden bestaat, waarvan jaarlijks 2 aftreden en, in vrije verkiezing door de Directing Council, door twee nieuwe vervangen worden. 
Tot op zekere hoogte heeft U.S. er wel de leiding. Een burger van U.S. was in de bijna 50 jaren van haar bestaan directeur van de P.A.S.O. Verleden jaar heeft men, aanvankelijk na andere plannen, deze gewoonte gecontinueerd. Maar dit jaar heeft men de aftredende onderdirecteur, ook een U.S. burger, door een Braziliaan vervangen. Overigens is de wil der U.S. in deze organisatie géén wet. Voorstellen door de delegatie van dit land met klem van redenen ingediend, en tegen hartstochtelijke aanvallen zakelijk en logisch verdedigd, worden soms met haast algemene stemmen verworpen, als ze niet op het laatste ogenblik ingetrokken worden om een nederlaag te voorkomen.

De functies van P.A.S.O. hebben, zoals de naam aanduidt, betrekking op de volksgezondheid in de aangesloten landen.

In de eerste plaats op die zaken die van internationaal belang zijn en dus niet door elk land naar eigen goeddunken te regelen zijn: Quarantaine ordonnanties, waaronder regels omtrent ontratting van schepen, ontmugging van vliegtuigen, vaccinatie voorschriften tegen pokken en gelekoorts vallen, buiten en behalve wat men meer in het bijzonder onder quarantaine voorschriften verstaat: het onderzoek en c.q. in quarantaine houden van scheeps- of luchtreizigers.

Maar er zijn meer activiteiten die niet tot quarantaine te rekenen zijn en die toch internationaal geregeld moeten worden. Een van de belangrijkste is de strijd tegen de muskiet Aedes aegypti, de overbrenger van de gele koorts in de steden en ook op het dicht bevolkte platteland. Veertig jaar geleden werd die strijd door Gorgas het eerst aangebonden, in Havana en Panamá. Met het doven van deze grote haarden van de ziekte was het met de gele koorts in Centraal Amerika gedaan. Enige jaren later volgden Rio de Janeiro en Guayaquil (Ecuador). Verscheidene jaren gold toen gele koorts als een voorbeeld van door mensenhanden uitgeroeide ziekte, tot zij in de vroege jaren ' 30 weer de kop op stak. $\mathrm{Nu}$ niet meer in steden of aan de kust, maar diep in het binnenland van Brazilië, in zeer schaars bewoonde streken waar pioniers hun kostgrondjes aan het oerwoud onttrokken. Dat was de zgn. "jungle yellow fever", echte gele koorts, maar overgebracht door muskieten die gewoonlijk niet met de mens in aanraking komen, en die de smetstof niet van mens op mens maar van aap op mens overbrengen. Op 't eerste gezicht zou men kunnen denken dat men zich van deze vorm der gele koorts niet veel hoeft aan te trekken. Ze komt immers niet bij de mens: de mens moet bij haar 
komen om van haar bestaan weet te krijgen. Maar een mens met haar besmet wordt pas 10 à 12 dagen later ziek. In dien tijd heeft hij wel eens een grote menselijke nederzetting bereikt waar de gele koorts-muskiet talrijk is. En als de immigrant dan ziek werd dan konden die muskieten zich gedurende de eerste drie dagen van zijn ziekte aan hem besmetten door zijn bloed te zuigen. En zo kon er dan een classieke gele koorts-epidemie tot stand komen. Dat is inderdaad wel eens gebeurd, en het gevaar was in de vroege jaren '30 groot. Men was zó overtuigd dat gelekoorts van het aardrijk verdelgd was, dat maatregelen tegen de Gk-muskiet allom verslapt waren daar waar ze vroeger met kracht uitgevoerd werden. En in landen waar men er vroeger niets aan gedaan had, dacht men er niet over er nu nog eens mede te beginnen. Zo schrikte de ontdekking der oerwouden gelekoorts de mensen wakker. Gele koorts was helemaal niet uitgeroeid. $\mathrm{Zij}$ had zich slechts terug getrokken in vestingen waarin de mens haar niet kan belagen. Maar zij kan de mens in steden en dorpen wél kwaad doen. Echter onder één voorwaarde: dat de mens daar met de gelekoortsmuggen samenwoont, dat in minstens $5 \%$ van de woningen en erven (van een stad of dorp) gelekoortsmuggen uitgebroed worden. Zijn de muskieten er niet, of zijn er maar weinig, dan heeft oerwoud gelekoorts op steden en dorpen geen vat. Maar de mens heeft op de oerwoud gelekoorts nooit vat. Dus blijft voortdurende waakzaamheid nodig; en die waakzaamheid moet zich uitstrekken niet alleen over onmiddellijk bedreigde streken, gelegen nabij de terreinen der oerwoud gelekoorts, maar over alle landen van de Nieuwe wereld waar Aedes aegypti broedt; van de Zuidelijke staten der Unie tot Noordelijk Argentinië toe.

De P.A.S.O. heeft zich tot taak gesteld deze waakzaamheid bij al haar leden op te wekken. En dat is haar gelukt. Alle 21 Republieken hebben zich verbonden de strijd tegen Aedes aegypti aan te binden volgens een vastgesteld plan; niet alleen wat de uitvoering betreft maar ook t.a.v. de toets die aangelegd moet worden om zekerheid te krijgen dat men het werk ook goed gedaan had.

De economisch zwakkeren onder de Republieken kregen daarbij steun van de P.A.S.O. in de vorm van experts om advies te geven, beurzen om leden van het sanitaire personeel in verder gevorderde Republieken te doen opleiden, uitrusting voor anti-Aedes . campagnes, en bijdragen in de kosten.

Sinds 1948 veroorzaakt oerwoud gelekoorts weer grote onrust 
in Centraal Amerika. Het begon met enige gevallen in de nabijheid van de stad Panamá, dus vlak bij de Canal Zone, waar zelfs het woord ,,gele koorts" nauwelijks genoemd mag worden, maar waar het oerwoud onmiddellijk aan grenst. Met behulp van P.A.S.O. en de Federal Health Service werd alles gedaan om de stad Panamá tegen een gelekoorts invasie te beschermen, door een intensieve anti-Aedes campagne. Bijna de gehele bevolking der Republiek Panamá werd bovendien tegen gelekoorts gevaccineerd. Dat men daarmede iets tegen de oerwoud gelekoorts zelf gedaan had verbeeldde zich natuurlijk niemand. Die smeulde rustig voort onder de apen der uitgestrekte wouden, en bereikte in 1951 Costa Rica, hetgeen ditmaal door een opvallende sterfte onder de apen en een groot aantal menselijke gelekoorts gevallen werd aangekondigd. Men verwacht dat de besmetting wel in Nicaragua en Yucatan zal doordringen. Alle steden in de bedreigde regionen zijn, naar men zegt, door een nooit eindigende antiAedes campagne voldoende beveiligd. Voor de bescherming van de landbewoners is vaccinatie het enige middel, waarvoor een beroep is gedaan op de drie leveranciers van gelekoorts vaccin in de Nieuwe Wereld: Hamilton, Bogotá en Rio de Janeiro.

Alles draait dus om muskietenbestrijding en vaccinatie.

In het net dat men om de gehele Aedes bevolking van de Nieuwe Wereld aan het dichttrekken is zitten echter gaten. Het omspant wel de 21 Republieken, maar niet het gehele Westelijke Halfrond.

Canada en Groenland vallen erbuiten. Voor de gelekoorts komt dat er niet op aan: zij liggen geheel buiten het Aedes-gebied. Of het niet meedoen van die twee ook t.a.v. andere gezondheidsproblemen onverschillig zal zijn is nog een open vraag. - Maar: die dan leeft, die dan zorgt.

Voor het Caraïbische gebied (in ruimere zin) is het een ander geval. Want daar liggen eilanden, en stukken van het vaste land (de Guiana's) die iets te maken hebben met de Europese landen Nederland, Engeland en Frankrijk, omdat die zgn. metropolitane gouvernementen er een zekere macht hebben, of verantwoordelijk zijn voor de buitenlandse betrekkingen van die landen. En dat zijn even zovele vacua in het systeem der anti-Aedes campagne in de landen van de P.A.S.O., evenals het vacua zijn in de overigens zo goed gesloten Amerikaanse Volkenbond. Het laatste is een zuiver politieke aangelegenheid, waarvan wij ons hier kunnen distanciëren. Maar, zo zult ge zeggen, zulke sanitaire vacua be- 
hoeven toch niet te bestaan; internationale samenwerking op sanitair gebied kan toch geheel losgemaakt worden van de politiek?

Vooruitgrijpende op een onderwerp dat ik later behandelen zal, wil ik nu reeds deze uitspraak als ongerechtvaardigd optimisme signaleren. Tijdens de laatste zitting der Directing Council te Washington verklaarde mij een gedelegeerde van een der grote Spaans-Amerikaanse landen, in een rustig en uiterst vriendschappelijk gesprek, dat zijn Regering er nooit in zou toestemmen dat P.A.S.O. voor haar jaarlijks budget bijdragen zou aanvaarden van een der Europese metropolitane gouvernementen. Want zo zou zijn Regering dat Gouvernement erkennen als machthebber over een groep eilanden welke zijn Regering van ouds rekende deel uit te maken van haar grondgebied. Daarbij noemde hij nog twee andere Spaans-Amerikaanse Republieken wier Regeringen er net eender over dachten. Nieuw was mij dit denkbeeld allerminst; reeds verleden jaar - en nog eerder uit de kranten - had ik er van gehoord. Maar dat een gedelegeerde mij er zo rustig, als iets van zelf sprekends, over kon onderhouden, was mij een nieuwe ervaring, die mij leerde dat deze zuiver humane gezondheidszorg volstrekt niet vrij is van de politiek.

In elk geval kan men zich zeer wel voorstellen dat zowel politieke personen, als zij die slechts het lichamelijk welzijn van hun medemensen willen bevorderen, deze vacua evenzeer verafschuwen als de natuur het in de ouderwetse physica heette te doen. De Politieken willen de vacua dichten door de Europeanen uit het Westelijk Halfrond te verdrijven. De Humanen willen de vacua door vreedzamer middelen doen verdwijnen. Welke die zijn zal ik $\mathrm{U}$ nu vertellen.

Om dit te doen moet ik eerst iets van de World Health Organisation (W.H.O.) zeggen. Ze is voor een groot deel voor de Oude Wereld wat P.A.S.O. voor de Nieuwe is, en haar verhouding tot Verenigde Naties is als die van P.A.S.O. tot de O.A.S. Met dit verschil dat niet alle leden van de U.N.O. lid van W.H.O. zijn.

Haar werkzaamheden kan ik hier hoogstens met enkele voorbeelden aanduiden. $\mathrm{Z}_{\mathrm{ij}}$ regelt met een voor haar leden bindende kracht de internationale sanitaire verplichtingen, door de World Health Assembly, de jaarlijkse vergadering van alle leden, vastgesteld. Zij steunt de leden-staten die het nodig hebben met haar teams van artsen, sanitaire ingenieurs, wijkzusters, en specialis- 
ten, op voorwaarde dat het betrokken land na enige jaren het werk van het team zal overnemen. Het werk van deze teams is demonstratie van de techniek en de uitwerking van sanitaire activiteit op allerlei gebied: bestrijding van bepaalde besmettelijke volksziekten, kinder- en moederzorg, bestrijding van voedsel deficienties etc. $Z$ ij werkt mede aan het behoud der volksgezondheid in geteisterde streken, zoals Korea. $\mathrm{Zij}$ verleent beurzen om artsen in de gelegenheid te stellen sanitair werk in andere landen te bestuderen. Zij roept in haar Expert Committees deskundigen uit verschillende landen bijeen om hun gemeenschappelijke opinie over hangende quaesties te formuleren. - Laat ik het bij deze enkele punten laten.

Bij deze werkzaamheden is decentralisatie nodig: niet alles kan van uit het hoofdkwartier der organisatie, het Palais des Nations te Genève, gebeuren. Deze decentralisatie wordt uitgevoerd door de oprichting van "Regionale Bureaux", elk bureau het hoofdkwartier van een "Regio" van de W.H.O., waarvan er nu in de oude wereld 5 zijn, nml. Europa, Afrika, Nabije Oosten, Z.O. Azië en Westelijke Stille Zuidzee.

Evenals alle leden van W.H.O. een stem hebben in de jaarlijks bijeenkomende algemene vergadering (de Assembly), zo is het ook met de Regionen. Die hebben elk ook hun Assembly. Stemgerechtigde leden daarvan zijn de zelfstandige staten in de Regio gelegen. Verder ook die staten wier regering niet in de Regio gevestigd is, maar die landen in de Regio beheersen, althans verantwoordelijk zijn voor hun buitenlandse betrekkingen. Wanneer zo een staat (metropolitaan gouvernement) meer dan één land in de Regio beheerst, of zijn buitenlandse betrekkingen verzorgt, heeft die staat in de Regio toch maar één stem. Het Verenigde Koninkrijk, bijvoorbeeld, heeft in de Assembly van de Afrikaanse Regio voor al zijn uitgestrekte, min of meer autonome landen (waaronder de Unie van $Z$. Afrika natuurlijk niet hoort) één stem, en het kleine Liberia heeft er ook één.

Zo is het in de oude wereld. Hoe is het nu in de nieuwe? Alle 21 Amerikaanse Republieken zijn lid van Verenigde Naties, evenals Canada. Groenland is door Denemarken lid. Maar dat betekent niet dat ze ook alle lid van W.H.O. zijn. In 1948 waren minstens 8 Republieken geen lid van die organisatie. Niet te verwonderen: in de P.A.S.O. hadden ze hun eigen Gezondheids Organisatie. Toch vond men dit niet een gewenste staat van zaken. Men wilde dat W.H.O. het grootst mogelijke deel van de wereld 


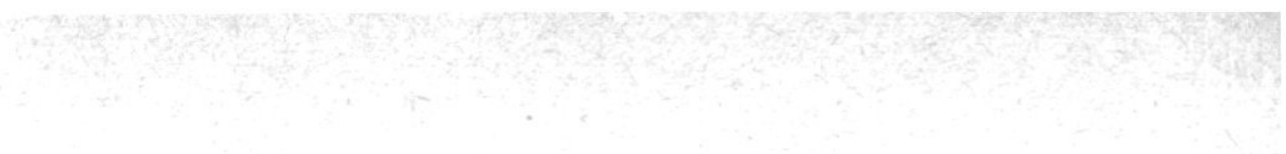

zou omvatten. Daarom kwam er vroeg in 1949 een overeenkomst tot stand tussen W.H.O. en P.A.S.O. waarbij P.A.S.O. erin toestemde te gaan functionneren als de Regionale Organisatie voor de W.H.O. in het Westelijke Halfrond, dat daarbij in zijn geheel tot Regio van W.H.O. werd. Dat betekende volstrekt niet, zoals sommigen ten onrechte uitspraken, dat P.A.S.O. in W.H.O. zou opgaan. P.A.S.O. bleef volkomen zelfstandig als een "specialized agency" van de Amerikaanse Volkenbond, met haar eigen budget, onafhankelijk van W.H.O. Maar de bijdrage van W.H.O. aan dat budget zou door P.A.S.O. beheerd en besteed worden, in overleg met de Directeur Generaal van W.H.O., en dat zou zij doen als Regionale Organisatie van W.H.O. P.A.S.O. zou echter pas als zodanig gaan fungeren wanneer $2 / 3$ van de Amerikaanse Republieken (14) lid van W.H.O. waren geworden. Dit aantal werd in de loop van 1949 bereikt, en van dat ogenblik af werd P.A.S.O. Regionale Organisatie van W.H.O. voor het Westelijk Halfrond, en P.A.S.B. Regionaal Bureau van W.H.O. voor dat Halfrond; dat Halfrond zelf werd de derde Regio van W.H.O. (Europa, Afrika en West-Pacific bestonden toen nog niet als Regionen).

Geheel zonder strijd kwam deze regeling, die uit een oogpunt van volksgezondheid niets anders tegen zich had dan dat ze niet ver genoeg ging, niet tot stand. Slechts schoorvoetend stemde de O.A.S. er in toe, dat haar zuiver Amerikaanse "specialized agency" zich in dienst stelde van een niet-Amerikaanse organisatie. Van een opgaan van P.A.S.O. in W.H.O. wilde zij niets weten. Men moet dit in het oog houden voor een goed begrip van wat nu volgt.

Als regio van W.H.O. viel het Westelijk Halfrond nu onder de bepaling die voor alle regionen van W.H.O. geldt, nml. dat staten buiten de regio gelegen één stem hebben in de Regionale Assembly, indien zij een of meer landen in de regio beheersen of er de buitenlandse betrekkingen van verzorgen. Wat betekende dat in dit geval? Dit: dat die staten één stem zouden hebben in de Directing Council van P.A.S.O. (eens per jaar) of in de P.A.S.Conference (eens in de vier jaar) voor zover die lichamen fungeerden als Regionale Organisatie van W.H.O.

In de vergadering van de Directing Council te Lima, October 1949, werd deze consequentie aanvaard. Artikel 9 van de resoluties van deze vergadering bepaalt dat bedoelde staten gelijk zullen staan met de Amerikaanse Republieken in de vergaderingen der Directing Council van P.A.S.O. (de Conference - de 
hoogste autoriteit - werd niet genoemd) indien deze vergadering fungeert als Regionale Organisatie van W.H.O. Men verzuimde echter criteria te bepalen welke zo'n vergadering kenmerken als functionnerende in dienst van W.H.O.

Door dit besluit werden de gedelegeerden van het Verenigde Koninkrijk, Nederland en Frankrijk, tot dien tijd toe slechts als waarnemers aanwezig, met één hamerslag stemgerechtigde deelnemers; Nederland ten gunste van Suriname en de Antillen. De gedelegeerde van een der Latijnse Republieken, vervaard voor de consequenties van dit, zijns inziens onbekookte, besluit, trachtte de situatie nog te redden door voor te stellen de nieuwe statenleden te ontheffen van de verplichting jaarlijks contributie aan P.A.S.O. op te brengen naar rato van hun bevolking in het Westelijk Halfrond. Het lid der Nederlandse delegatie dat de Antillen vertegenwoordigde maakte toen, zeer ter snede, de opmerking dat hier het omgekeerde van een zeker bekend gezegde van toepassing was, nml. "no representation without taxation". De Franse delegatie stemde hier mee ten volle in, en het voorstel kwam niet eens in behandeling - Maar het was niettemin zeer juist gezien.

Wat won P.A.S.O. met dit besluit? Dit: dat de vacua werden gevuld. De medewerking was nu verzekerd van alle landen in het Caraïbische gebied t.a.v. de Aedes-uitroeiïng. Ik wil volstrekt niet beweren dat die medewerking er niet reeds was. Maar ik geloof niet te veel te zeggen wanneer ik beweer dat zij krachtiger werd, zeer krachtig zelfs in Suriname. Daar was nog een bijzondere reden voor, deze nml. dat in de binnenlanden van Suriname oerwoud-gelekoorts voorkomt. Wel niet explosief, zoals nu in Panamá en Costa Rica, maar zij is er toch, en zij levert een potentieel gevaar op. Ook Nederland zelf, de Regering en het Instituut voor de Tropen, werkt nu mede: de Regering door jaarlijks een delegatie naar de Directing Council te zenden, het Instituut voor de Tropen door hiervoor jaarlijks een van zijn ambtenaren af te staan, door het meest bedreigde gebied tegen kostprijs van gelekoorts-vaccin te voorzien, en, voor gevallen van urgentie, een grote voorraad vaccin als renteloos kapitaal in voorraad te houden.

Het besluit van Lima werd 's nachts te half twee in een zitting die de hele dag geduurd had, genomen. Men had blijkbaar de volle consequenties niet overzien. Want die waren niet minder dan dit, dat vreemdelingen, niet-Amerikanen, vertegenwoordigers van Regeringen die Amerikaans grondgebied beheersten, grond- 
gebied dat vrij behoorde te zijn, of deel moest uitmaken van deze of gene Amerikaanse Republiek, nu met stemrecht zitting namen in zuiver Amerikaanse vergaderzalen, en geldelijk bijdroegen aan een zuiver Amerikaanse Organisatie.

Maar er bleef nog een uitweg over, en het volgend jaar, in Ciudad Trujillo, deden de Politieken alles om die open te houden.

Die uitweg was de bepaling dat de metropolitane gouvernementen hun recht in de Directing Council alleen kunnen uitoefenen als die Raad fungeert als Regionale Organisatie van W.H.O.

Hiervoor hadden de Humanen een fraaie omzeiling van de moeilijkheid bedacht, die zelfs de vertegenwoordiger van de O.A.S. kon bevredigen. Het zou mij te ver voeren uit te leggen waarin die omzeiling van de beperkende bepaling bestond. Genoeg zij het te zeggen dat zij in de betrokken hoofdcommissie van de Directing Council door de minderheid, de Politieken, werd verworpen, maar door de meerderheid, de Humanen werd aanvaard, evenwel in de plenaire zitting der Directing Council werd ingetrokken. Daarentegen werd de metropolitanen-gedelegeerden dezelfde positie in de P.A.S.-Conference verleend die zij in de Directing Council hadden. Maar een nadere bepaling van deze positie werd naar de vergadering van een jaar later verwezen.

Twee jaar na Lima, in Washington 1951, werd door de Directing Council een besluit genomen waarin vrij duidelijk werd omschreven onder welke omstandigheden de Directing Council een orgaan van W.H.O. is, waarin de metropolitane gedelegeerden wél stemrecht hebben, en wanneer niet. Het werd slechts door één Politieke niet aanvaard. Maar toen het er op aan kwam dit besluit uitvoerbaar te maken, door zekere wijzigingen in de regelen van procedure van de Directing Council aan te brengen, besloot men op advies van dezelfde Politieke de behandeling van de wijziging tot het volgend jaar uit te stellen. Daarentegen nam men wél een besluit waardoor de geldelijke bijdragen der metropolitane gouvernementen (die inmiddels door één over 1950 en 1951 en door een tweede over 1951 waren gestort) nader werden berekend - en daartegen verzette zelfs die ene meest politieke onder de Politieken zich niet.

Tenslotte: Al deze strubbelingen zijn niet zo belangrijk. Waar het op aankomt is dit: dat geregeld contact en uitwisseling van gedachten met P.A.S.O. tot stand is gekomen en in stand wordt gehouden, en dat er een daadwerkelijke samenwerking mogelijk is gebleken welke, zo mag men verwachten, in omvang en betekenis zal toenemen. 


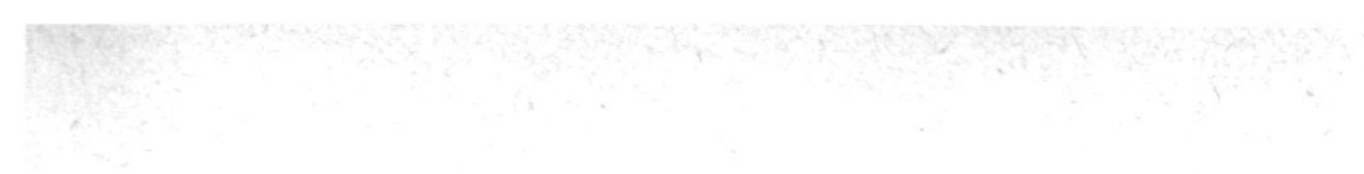

\section{SUMMARY}

The Pan American Sanitary Organisation (P.A.S.O.)

in relation with Suriname and the Netherlands Antilles

In International Relations the New World is far in advance of the Old World. From 1890 onward, the American States are organised in a „League of Nations”, the Union of American Republics which, since 1948, bears the name of Organisation of American States. Like the United Nations Organisation, this Union is assisted by specialized agencies. One of them, the Pan American Sanitary Organisation, is the senior of her sister, the World Health Organisation, by little less than half a century. In October 1949 the elder sister put her whole equipment at the disposal of the younger, by consenting to act as the Regional Organisation of W.H.O. in the Western Hemisphere, without, however, relinquishing one particle of her independence. This generous act had one serious, although not unforeseen, consequence: it introduced into this purely American circle certain European Governments, members of W.H.O., closely associated with territories in the Western Hemisphere forming no part of any of the twenty-one American Republics.

The admittance of these Governments to the membership of P.A.S.O. was qualified by the following clauses: (1) they are not members, but they share the rights of the members; (2) they do so only when the Directing Council of P.A.S.O. is acting as Regional Organisation of W.H.O. On these conditions representatives of France, the Netherlands, and the United Kingdom were admitted as members to the latter part of the meeting of the Directing Council at Lima (Peru), October 1949. No rules were laid down, however, which would allow one to make sure whether or not any Directing Council in session is acting as Regional Organisation of W.H.O.

The next meeting of the Directing Council (Ciudad Trujillo, Dominican Republic, September 1950) was not completely successful in its attempt to rectify this omission. So it was left to the meeting at Washington D.C. (1951) to define the characteristics of a Directing Council acting as Regional Organisation of W.H.O. in the Western Hemisphere. But even now the delegates of the above European Governments are not allowed to enjoy the rights conferred on them at the Lima meeting, untul the afore mentioned definition has been incorporated into the Rules of Procedure of the Directing Council of P.A.S.O.

Nevertheless far reaching co-operation has been established between P.A.S.O. on one side, and the Governments of the Netherlands, Surinam, and the Netherlands Antilles on the other, the Royal Tropical Institute at Amsterdam serving the latter in various capacities. At a time when renewed activity of jungle yellow fever is requiring the utmost vigilance in all American States, this co-operation is highly valuable, and fully justifies the continuance of delegates from these countries attending the meetings of the Directing Council of P.A.S.O. 